Fatemeh Zahra Amirmohammadi*, Majid Azizi, Seyyed Hossein Nemati, Marcello Iriti* and Sara Vitalini

\title{
Analysis of the essential oil composition of three cultivated Nepeta species from Iran
}

https://doi.org/10.1515/znc-2019-0206

Received November 14, 2019; revised January 20, 2020; accepted January 21, 2020

\begin{abstract}
Essential oils (EOs) of three Iranian cultivated Nepeta species were investigated. The oils were obtained by hydrodistillation of air-dried plant materials at full flowering stage and analyzed by gas chromatography (GC) and gas chromatography coupled to mass spectroscopy (GC/MS). In total, 89 compounds were detected. In over 2 years, a number of constituents were identified in the EO of Nepeta binaloudensis first and second years (26 and 37, respectively), Nepeta cataria (25 and 32, respectively), and Nepeta assurgens (45 and 50, respectively). In the oils of $N$. binaloudensis, 4a- $\alpha, 7-\alpha, 7 \mathrm{a}-\alpha$-nepetalactone (NL) $59.7 \%$ and 1,8-cineole (19.6\%) during the first and second years, respectively, were the main constituents. The main components of $N$. cataria were $4 \mathrm{a}-\alpha, 7-\alpha, 7 \mathrm{a}-\beta-\mathrm{NL}(72.8 \%)$ and $4 a-\alpha, 7-\beta, 7 a-\alpha-N L$ (73.9\%) during the first and second years, respectively, and $4 \mathrm{a}-\alpha, 7-\alpha, 7 \mathrm{a}-\alpha-\mathrm{NL}$ (55.5\%) and 1,8-cineole (24.1\%) during the first and second years, respectively, were the main constituents of $N$. assurgens. The results showed that NLs isomers and 1,8-cineole were the main components of the oils of three cultivated Nepeta species.
\end{abstract}

Keywords: 1,8-cineole; Nepeta assurgens; Nepeta binaloudensis; Nepeta cataria; nepetalactone.

\section{Introduction}

Nepeta is one of the largest genera of the subfamily Nepetoideae and family Lamiaceae. It comprises

\footnotetext{
*Corresponding authors: Fatemeh Zahra Amirmohammadi, Department of Horticultural Sciences, Faculty of Agriculture, Ferdowsi University of Mashhad, 9177948974 Mashhad, Iran, E-mail: fz_amirmohamadi@mail.um.ac.ir; and Marcello Iriti, Department of Agricultural and Environmental Sciences, Milan State University, 20133 Milano, Italy, E-mail: marcello.iriti@unimi.it. https://orcid.org/0000-0002-5063-1236

Majid Azizi and Seyyed Hossein Nemati: Department of Horticultural Sciences, Faculty of Agriculture, Ferdowsi University of Mashhad, 9177948974 Mashhad, Iran

Sara Vitalini: Department of Agricultural and Environmental Sciences, Milan State University, 20133 Milano, Italy
}

approximately 300 species, which are often perennial herbs. Nepeta species are distributed in the central and southern parts of Europe, Asia, and the Middle East. Iran is one of the main centers of diversity for the genus with about 79 species naturally growing in different regions of the country [1-3]. The genus Nepeta was attributed with a number of pharmacological effects. The application of essential oils (EOs) against microorganisms increased, and it is known that Nepeta oils also have such effects. The EOs of this genus were found to be rich in iridoid monoterpenoids, which exhibited many in vitro/in vivo biological activities including antioxidant, antimicrobial, anti-inflammatory, cytostatic, phytotoxic, and repellent properties [4-10]. In general, bioactivities of Nepeta EOs are attributed to the presence of nepetalactones (NLs) that have been used as the phytochemical markers.

In this study, we investigated the EO composition of three cultivated species of Nepeta in 2 years (Nepeta assurgens, Nepeta binaloudensis Jamzad, Nepeta cataria L.), two of which are endemic (Table 1). Briefly, N. assurgens is an herbaceous aromatic plant growing in dry areas of Kerman, Iran. Kerman province is a unique center of medicinal plants in the country. Nepeta binaloudensis is an endemic and rare perennial aromatic herb, which is distributed in a limited area in Binalud Mountains, Khorasan Razavi Province in North-East of Iran [11], which is used as a culinary herb, and $N$. cataria, the most intensively studied species, is commonly known as catnip or catmint because of its irresistible action on cats.

The biological and chemical diversity, species richness, as well as biological properties greatly promoted the research focusing on this genus [4]. Until now, 143 compounds were identified in the various species of this genus [12], mainly including nepetalactones, $\beta$-caryophyllene, caryophyllene oxide, 1,8-cineol, $\alpha$-humulene, citronellol, linalool, geraniol, geranial, geranyl acetate, spathulenol, citronellyl acetate, germacrene-D, $\alpha$-pinene, and camphor. However, in a number of Nepeta species, NLs are either present as minor components or are not produced at all. In general, according to EO composition, the various species of Nepeta may be divided into two main groups: in the first group, NLs are the dominant constituents; in the second group, compounds such as 1,8-cineole, 
Table 1: Nepeta species investigated in this study and their harvesting data.

\begin{tabular}{|c|c|c|c|}
\hline Taxon & Collection locality & $\begin{array}{r}\text { Collection date and } \\
\text { elevation }(\mathrm{m})\end{array}$ & $\begin{array}{l}\text { Herbarium } \\
\text { voucher no. }\end{array}$ \\
\hline $\begin{array}{l}\text { Nepeta assurgens Hausskn. \& } \\
\text { Bornm. ex Bornm }{ }^{\text {a }}\end{array}$ & $\begin{array}{l}\text { Kerman province, Darb-e Behesht, } \\
\text { mountain slopes of Bahrasman }\end{array}$ & 20.09.2017 (3323) & $\begin{array}{l}\text { ANRRCIH } \\
8636\end{array}$ \\
\hline Nepeta binaloudensis Jamzad & $\begin{array}{l}\text { Razavi Khorassan Province, Zoshk, } \\
\text { Binaloud mountains }\end{array}$ & $29.09 .2015(2400)$ & $\begin{array}{l}\text { FUMH } \\
46489\end{array}$ \\
\hline Nepeta cataria L. & $\begin{array}{l}\text { Razavi Khorassan481.89 Province, } \\
\text { Mashhad }\end{array}$ & 20.08.2017 (1010) & $\begin{array}{l}\text { FUMH } \\
44565\end{array}$ \\
\hline
\end{tabular}

ANRRCKH, Agricultural and Natural Resources Research Center of Kerman, Herbarium; FUMH, Ferdowsi University of Mashhad, Herbarium. ${ }^{a}$ Endemic of Iran.

caryophyllene, citral derivatives, and $\alpha$-humulene are dominant [2, 12-18].

Furthermore, many of these species are considered of horticultural and medicinal interests in arid and semi-arid areas, due to their long flowering period, adaptation to drought conditions, as well as their high EO and phenolic compound contents [6, 19-21]. However, there are many species and constituents of EO that have not been studied yet.

In plants, the EO composition and secondary metabolite diversity are extremely dependent on environmental factors, such as light, temperature, water, soil salinity, and climatic conditions. Plant collecting from the wild could lead to further loss of genetic diversity and habitat destruction. Some previous studies highlighted the possibility of domestic cultivation of these valuable medicinal plants. Introduction into cultivation under controlled environments represents a great challenge that could modify the content of bioactive phytochemicals and lower the pressure on wild populations [22-25]. Thus, investigations of new, as well as known plant species from different geographic regions may considerably expand the existing knowledge on the EO-bearing plants [12].

Therefore, the aim of the present study was to investigate the EO composition of three Nepeta species and evaluate the NL isomer content in order to select the most suitable species for domestication and cultivation under the same conditions, and to meet the market and consumer needs.

\section{Materials and methods}

\subsection{Plant material}

The research was conducted in the Experimental Garden of Agricultural Faculty of Ferdowsi University of Mashhad,
Iran, in 2016-2018. The seeds of three Nepeta species were collected from Kerman and Mashhad provinces of Iran. The origin of plant material, year of collection, and herbarium voucher are presented in Table 1.

\subsection{Cultivation conditions}

The seeds were placed at $4{ }^{\circ} \mathrm{C}$ for 2 weeks, then sown under greenhouse-controlled conditions with a temperature range of $20^{\circ}-25^{\circ} \mathrm{C}$ and relative humidity of $60^{\circ} \mathrm{C}$ (latitude: $36^{\circ} 16^{\prime} \mathrm{N}$, longitude: $59^{\circ} 36^{\prime} \mathrm{E}$ ) during the last week of March. The culture bed contained peat moss, cocopeat, and perlite (40:40:20, w:w:w). After about 30 days, seedlings were transplanted into pots of $30-\mathrm{cm}$ height, with the same composition of the first bed; after about 45 days, seedlings were transplanted to the field, on the base of completely randomized design including three replications $\left(1.5 \times 2 \mathrm{~m}^{2}\right.$ plot $)$ in the Experimental Garden of Ferdowsi, University of Mashhad. Based on the climatic conditions, the plants were irrigated to maintain nearfield capacity. The characteristics of the field location are reported in Table 2.

\subsection{Extraction of the EOs}

During the summer, aerial parts of the plants were harvested at full flowering stage in the first and second year (about 120 and 360 days after cultivation) of their establishment on the farm. Plants were harvested at $5 \mathrm{~cm}$ above the soil level and then air-dried in the shade.

The EOs from the dry plants ( $30 \mathrm{~g}$ ) of two cuts, during the first and second years, were extracted by hydro-distillation for $4 \mathrm{~h}$ using a Clevenger apparatus (Ashk shishe Co., Tehran, Iran), and the EO yield percentage was 
Table 2: Soil characteristics and meteorological conditions of the experimental field where Nepeta species were cultivated.

\begin{tabular}{|c|c|c|}
\hline Physical and chemical properties & $(2016-2017)$ & (2017-2018) \\
\hline Clay \% & 26 & 26.5 \\
\hline Silt \% & 48 & 49.1 \\
\hline Sand \% & 26 & 24 \\
\hline Soil texture & Sandy loam & Sandy loam \\
\hline $\mathrm{FC}^{\mathrm{a}}$ & 15 & - \\
\hline $\mathrm{CCE}^{\mathrm{b}}$ & 12.5 & - \\
\hline $\mathrm{pH}$ & 7.28 & 7.8 \\
\hline$E C^{c}\left(\mathrm{dSm}^{-1}\right)$ & 3.70 & 2.21 \\
\hline Organic matter \% & 0.78 & - \\
\hline $\mathrm{Ca} \%$ & 0.08 & - \\
\hline Available N (mg/kg) & 16.5 & 11.8 \\
\hline Available P (mg/kg) & 19.4 & 14.7 \\
\hline Available K (mg/kg) & 334 & 278 \\
\hline Available Mg (ppm) & 11 & - \\
\hline Available Cu (ppm) & 1.27 & - \\
\hline Available Mn (ppm) & 7.92 & - \\
\hline Available Zn (ppm) & 1.93 & - \\
\hline Available Fe (ppm) & 1.51 & - \\
\hline Meteorological data & $(2016-2017)$ & $(2017-2018)$ \\
\hline Altitude (m) & 985 & 985 \\
\hline Annual minimum temperature $\left({ }^{\circ} \mathrm{C}\right)$ & 9.1 & 9.9 \\
\hline Annual maximum temperature $\left({ }^{\circ} \mathrm{C}\right)$ & 22.4 & 23 \\
\hline Annual mean temperature $\left({ }^{\circ} \mathrm{C}\right)$ & 15.7 & 17.2 \\
\hline Absolute humidity mean (\%) & 46 & 44 \\
\hline Annual precipitations (mm) & 308.1 & 185.9 \\
\hline Number of ice days & 17 & 61 \\
\hline Number of rainy days & 97 & 67 \\
\hline
\end{tabular}

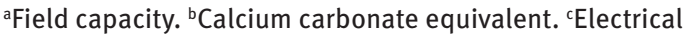
conductivity.

recorded as $\% \mathrm{v} / \mathrm{w}$ of plant dry weight. Sodium sulfate anhydrous purchased from Sigma (St Gallen, Switzerland) was added for removing water from the isolated EOs that was stored in a refrigerator in dark bottles until analyses.

\subsection{Gas chromatography (GC) and gas chromatography coupled to mass spectroscopy (GC/MS) (GC/MS) analysis}

The composition analysis of the essential oil samples of the first and second years was carried out using a GC-MS instrument with the following specifications: GC analysis was carried out using an Agilent-Technologies-7890A gas chromatograph equipped with an HP-5 column (30 $\mathrm{m} \times 0.32 \mathrm{~mm}$ ID) and film thickness of $0.25 \mu \mathrm{m}$. The oven temperature was from $60^{\circ} \mathrm{C}$ and then programmed to $210^{\circ} \mathrm{C}$ at a flow rate of $3^{\circ} \mathrm{C} / \mathrm{min}$, then from $210^{\circ} \mathrm{C}$ to $240{ }^{\circ} \mathrm{C}$ at $20{ }^{\circ} \mathrm{C} / \mathrm{min}$ and held for $8.5 \mathrm{~min}$; injector and detector (FID) temperature were $280^{\circ} \mathrm{C}$ and $290^{\circ} \mathrm{C}$, respectively; $\mathrm{N}_{2}$ was used as carrier gas with a linear velocity of $1 \mathrm{~mL} / \mathrm{min}$, split ratio was 1:50.

GC/MS analyses were carried out on GC/MS (Agilent Technologies-5975C-MS, 7890A-GC) equipped with HP-5MS capillary column $(30 \mathrm{~m} \times 0.25 \mathrm{~mm}$ ID) and film thickness of $0.25 \mu \mathrm{m}$. The oven temperature was programmed as follows: from $60{ }^{\circ} \mathrm{C}$ to $210{ }^{\circ} \mathrm{C}$ with a rate of $3{ }^{\circ} \mathrm{C} / \mathrm{min}$, then increased to $240{ }^{\circ} \mathrm{C}$ with a rate of $20{ }^{\circ} \mathrm{C} /$ $\mathrm{min}$, and the final temperature was kept for $8.5 \mathrm{~min}$; run "time" was $60 \mathrm{~min}$. The electron ionization energy was $70 \mathrm{eV}$ in the electronic ionization (EI) mode, ion source $230{ }^{\circ} \mathrm{C}$, detector MS, interface line temperature $280{ }^{\circ} \mathrm{C}$, injector $280^{\circ} \mathrm{C}$, split ratio 1:50, carrier gas $\mathrm{He} 1 \mathrm{~mL} / \mathrm{min}$, mass range 50-480 amu.

The percentages of compounds were calculated by the area normalization method. The components of the oil were identified by comparison of retention indices (RI, HP-5) in their mass spectra with those of an Adams library and sorted in NIST and Wiley libraries or with authentic compounds reported in the literature. Retention indices were determined using retention times of $n$-alkane that were injected after the EO under the same chromatographic conditions [26].

\subsection{Statistical analysis of EO yields}

Mean values and variance analysis of EO yields were calculated according to a completely randomized design including three replications for each year. Statistical analysis of the obtained results was performed by (JMP software ve. 9.0.3). Significant differences among the samples were evaluated by Duncan test at the probability level $(\mathrm{p} \leq 0.05)$.

\section{Results}

\subsection{EO yields}

Results of the EO yields from the three Nepeta species for 2 years are reported in Table 3. The EOs extracted from the $N$. assurgens and $N$. binaloudensis species were yellow, whereas the $N$. cataria was whitish-yellow in color. There were significant differences in the EO yield among the species. The highest EO yields were obtained from $N$. assurgens in 2 years $(0.51 \%$ and $0.75 \%$ in the first and second years, respectively). The yields of $N$. cataria 
Table 3: Analysis of variances and means of essential oil yields among cultivated $N$. binaloudensis, $N$. cataria, and $N$. assurgens species during 2016/2018.

\begin{tabular}{llr}
\hline Sources & Df & Means of squares \\
\cline { 3 - 3 } & & Essential oil yield (\%) \\
\hline 1st year & 2 & \\
Species & 2 & $0.0613^{\mathrm{a}}$ \\
Replications & 4 & 0.0085 \\
Error & & 0.0010 \\
2nd year & 2 & \\
Species & 2 & $0.2585^{\mathrm{a}}$ \\
Replications & 4 & 0.0009 \\
Error & Species & 0.0080 \\
\hline Cultivation year & N. binaloudensis & Yield (\%) \\
\hline 1st year & $N$. cataria & $0.23^{\mathrm{b}}$ \\
& $N$. assurgens & $0.32^{\mathrm{c}}$ \\
& $N$. binaloudensis & $0.51^{\mathrm{a}}$ \\
2nd year & $N$. cataria & $0.18^{\mathrm{b}}$ \\
& $N$. assurgens & $0.29^{\mathrm{c}}$ \\
& & $0.74^{\mathrm{a}}$ \\
\hline
\end{tabular}

Means having the same letter within the same column are not significantly different. a Significant at $p \leq 0.05$.

were $0.32 \%$ (first year) and $0.29 \%$ (second year), whereas $N$. binaloudensis yielded the lowest amounts $(0.23 \%$ and $0.18 \%$ in the first and second years, respectively) (Table 3 ).

\subsection{The composition of EOs}

The constituents of the Nepeta EOs analyzed by GC and GC-MS are reported in Table 4. In total, 89 constituents were identified. During 2 years of cultivation, a number of constituents were identified in the EOs of $N$. binaloudensis in the first and second years (26 and 37, respectively), $N$. cataria (25 and 32, respectively) and $N$. assurgens (45 and 50, respectively) The results indicated that there were differences between the species in the first and second years in EO composition and number of compounds. The EOs were rich in monoterpenoids, as other Nepeta species previously reported. In the oils of $N$. binaloudensis, 4a- $\alpha, 7-\alpha, 7 \mathrm{a}-\alpha-\mathrm{NL}(1.2-59.7 \%)$ and 1,8-cineole (14.8-19.6\%) were the main components in the 2 years. Other abundant constituents included $\beta$-pinene (10.4\%), p-cymene (9.7\%), $\alpha$-terpineol (7\%), $\gamma$-terpinene $(4.5 \%), \alpha$-pinene $(4.33 \%)$, terpinen-4-ol (4.2\%), $\delta$-terpineol (3.61\%), and thymol $(1.7 \%)$ in the first year. Thymol, carvacrol $(0.6 \%), \alpha$-copaene $(0.2 \%)$, $\beta$-copaene $(0.1 \%), \beta$-bourbonene $(1.0 \%), 4 \mathrm{a}-\alpha, 7-\alpha, 7 \mathrm{a}$ $\beta$-NL (NL2) (0.9\%), germacrene-D (0.2\%), $\gamma$-muurolene
$(0.3 \%)$, and $\gamma$-terpinene were identified only in the first year, whereas $4 \mathrm{a}-\alpha, 7-\beta, 7 \mathrm{a}-\alpha-\mathrm{NL}(0.9 \%)$ was detected only during the second year. The EOs of $N$. cataria were rich in NL isomers, while in the second year, the main compound was $4 a-\alpha, 7-\alpha, 7 a-\beta-N L(72.8 \%)$. In general, $4 a-\alpha, 7-$ $\beta, 7 a-\alpha-N L(2.5-73.9 \%)$ and $4 a-\alpha, 7-\alpha, 7 a-\alpha-N L(17.9-19.8 \%)$ in the first and second years, respectively, were quantified as the main components in this species. In the EOs of $N$. assurgens, 4a- $\alpha, 7-\alpha, 7 \mathrm{a}-\alpha-\mathrm{NL}(34.7-55.5 \%)$ and 1,8cineole $(24.1-16.8 \%)$ were the main constituents in the first and second years, respectively. Other compounds included $\beta$-pinene (3.9-4.6\%), trans-carveol (6.7-2.2\%), NL2 (5.7\% only in the first year), and $4 \mathrm{a}-\alpha, 7-\beta, 7 \mathrm{a}-\alpha-\mathrm{NL}$ $(2.7 \%)$ only in the second year.

\section{Discussion}

\subsection{EO yields}

The yields of EOs from the studied Nepeta species were from $0.18 \%$ ( $N$. binaludensi) to $0.79 \%$ ( $N$. assurgens). In previous studies, EO yields of $N$. cataria were in the range of $0.1-2.5 \%$, in plants from different regions (Table 5), whereas the yield of $N$. binaludensis collected in Iran was $0.74 \%$ [11]. Therefore, the previously reported EO yields from $N$. cataria were remarkably higher: $2.5 \%$ [19] and $1.02 \%$ [8] from plants cultivated in Iran and Morocco, respectively. To the best of our knowledge, the yields of EO from $N$. assurgens were not reported previously. Noteworthy, the variability of EO yields during the 2 years may be attributed to environmental factors possibly modifying photosynthate allocation to secondary metabolic pathways [20-25].

\subsection{The composition of EOs}

Biological activities of NLs were thoroughly investigated, and some Nepeta species were previously introduced into cultivation due to their horticultural and medicinal values [16, 19-21]. Most EOs of the Nepeta species contain NLs as the main components, though different oil compositions were identified among the different species. In the present study, three types of NL isomers, 4a- $\alpha, 7-\alpha, 7 a-\alpha-N L, 4 a-\alpha, 7-$ $\alpha, 7 a-\beta-N L$, and $4 a-\alpha, 7-\beta, 7 a-\alpha-N L$, were identified. All these $\mathrm{NL}$ isomers were the dominant components of the oils of $N$. cataria, whereas in $N$. assurgens and $N$. binaloudensis, other constituents were significantly present besides 4a- $\alpha, 7-\alpha, 7 \mathrm{a}-\alpha-\mathrm{NL}$, in particular, 1,8-cineole. 
Table 4: Number and percentage of the essential oil constituents from the three cultivated Nepeta species in 2 years.

\begin{tabular}{|c|c|c|c|c|c|c|c|c|c|}
\hline \multirow[t]{3}{*}{ No. } & \multirow[t]{3}{*}{ Compounds } & \multirow{2}{*}{\multicolumn{2}{|c|}{$\begin{array}{r}\text { Retention } \\
\text { index }\end{array}$}} & \multicolumn{6}{|l|}{$\%$} \\
\hline & & & & \multicolumn{2}{|c|}{ N. binaloudensis } & \multicolumn{2}{|l|}{ N. cataria } & \multicolumn{2}{|c|}{ N. assurgens } \\
\hline & & $\mathbf{R}^{\mathbf{a}}$ & $\mathbf{R} \mathbf{I}^{\mathbf{b}}$ & 1st year & 2nd year & 1st year & 2nd year & 1st year & 2nd year \\
\hline 1 & (E)-2-Hexenal & 948 & 848 & - & - & - & 0.1 & - & - \\
\hline 2 & Tricyclene & 919 & 919 & $\operatorname{tr}$ & - & - & - & 0.2 & 0.1 \\
\hline 3 & $\alpha$-Thujene & 925 & 926 & 1.2 & 0.5 & $\operatorname{tr}$ & $\operatorname{tr}$ & 0.1 & 0.1 \\
\hline 4 & $\alpha$-Pinene & 932 & 933 & 4.3 & 0.6 & 0.7 & 0.1 & 1.4 & 3.6 \\
\hline 5 & Camphene & 947 & 948 & 0.2 & 0.1 & 0.1 & $\operatorname{tr}$ & $\operatorname{tr}$ & 0.1 \\
\hline 6 & Thuja-2,4(10)-diene & 953 & 953 & - & - & - & - & - & $\operatorname{tr}$ \\
\hline 7 & Sabinene & 973 & 972 & 0.3 & 0.8 & 0.5 & 0.1 & 0.4 & 1.7 \\
\hline 8 & $\beta$-Pinene & 978 & 977 & 10.4 & 1.8 & 2.2 & 0.5 & 3.9 & 4.6 \\
\hline 9 & 3-Octanone & 985 & 985 & - & - & $\operatorname{tr}$ & $\operatorname{tr}$ & 0.3 & 0.2 \\
\hline 10 & Myrcene & 992 & 990 & 1.6 & 1.4 & $\operatorname{tr}$ & $\operatorname{tr}$ & 0.6 & 2.8 \\
\hline 11 & n-Decane & 1000 & 1000 & 6.2 & 0.1 & $\operatorname{tr}$ & 0.1 & 3.2 & - \\
\hline 12 & $\alpha$-Phellandrene & 1006 & 1004 & 0.3 & 0.2 & - & - & - & - \\
\hline 13 & $\alpha$-Terpinene & 1016 & 1017 & 2.7 & 0.3 & - & $\operatorname{tr}$ & 0.1 & 0.2 \\
\hline 14 & p-Cymene & 1024 & 1024 & 9.7 & 4.2 & 0.1 & 0.1 & 0.7 & 0.1 \\
\hline 15 & Limonene & 1029 & 1028 & 2.2 & 0.3 & 0.1 & 0.1 & 0.3 & 0.2 \\
\hline 16 & 1,8-Cineole & 1030 & 1033 & 14.8 & 19.6 & 0.2 & 0.5 & 24.1 & 16.8 \\
\hline 17 & (Z)- $\beta$-Ocimene & 1037 & 10.36 & 0.9 & 0.2 & - & 0.0 & 0.2 & 0.9 \\
\hline 18 & (E)- $\beta$-Ocimene & 1046 & 1046 & 0.2 & 0.1 & - & 0.1 & - & 0.2 \\
\hline 19 & $\gamma$-Terpinene & 1057 & 1057 & 4.5 & - & - & $\operatorname{tr}$ & 0.3 & 0.2 \\
\hline 20 & cis-Sabinene hydrate & 1067 & 1066 & 0.3 & 0.5 & - & - & - & 0.2 \\
\hline 21 & trans-Linalool oxide & 1071 & 1071 & - & - & - & - & 0.1 & $\operatorname{tr}$ \\
\hline 22 & Terpinolene & 1088 & 1089 & 1.3 & 0.3 & $\operatorname{tr}$ & 0.1 & 0.3 & 0.2 \\
\hline 23 & Linalool & 1098 & 1099 & 1.8 & 1.2 & - & $\operatorname{tr}$ & 0.9 & 0.8 \\
\hline 24 & 3-Methyl butyl 2-methyl butanoate & 1104 & 1101 & 0.2 & 0.1 & - & - & - & 0.2 \\
\hline 25 & n-Nonanal & 1105 & 1105 & - & - & $\operatorname{tr}$ & $\operatorname{tr}$ & - & - \\
\hline 26 & Isopentyl isovalerate & 1106 & 1106 & $\operatorname{tr}$ & - & - & - & 0.1 & 0.1 \\
\hline 27 & cis-Rose oxide & 1111 & 1111 & - & - & - & - & 0.1 & - \\
\hline 28 & endo-Fenchol & 1113 & 1113 & - & - & - & - & 0.1 & - \\
\hline 29 & cis-p-Menth-2-en-1-ol & 1121 & 1121 & 0.6 & 0.1 & - & - & 0.2 & 0.1 \\
\hline 30 & $\alpha$-Campholenal & 1126 & 1126 & 0.2 & - & - & - & 0.4 & 0.1 \\
\hline 31 & allo-Ocimene & 1128 & 1128 & - & - & - & - & - & 0.1 \\
\hline 32 & trans-Pinocarveol & 1138 & 1136 & - & 0.1 & - & $\operatorname{tr}$ & 0.9 & 0.2 \\
\hline 33 & Nopinone & 1137 & 1137 & - & 0.2 & - & - & 0.1 & - \\
\hline 34 & trans-p-Menth-2-en-1-ol & 1138 & 1138 & - & 0.6 & - & - & - & - \\
\hline 35 & Geijerene & 1141 & 1141 & - & - & - & - & - & 0.1 \\
\hline 36 & Camphor & 1145 & 1144 & - & $\operatorname{tr}$ & $\operatorname{tr}$ & 0.1 & - & - \\
\hline 37 & trans-Verbenol & 1145 & 1146 & - & - & - & - & - & 0.1 \\
\hline 38 & Citronellal & 1154 & 1152 & - & - & - & - & - & 0.1 \\
\hline 39 & Pinocarvone & 1162 & 1162 & 0.2 & 0.1 & - & $\operatorname{tr}$ & 0.3 & 0.1 \\
\hline 40 & $\delta$-Terpineol & 1166 & 1166 & 3.6 & 1.1 & - & $\operatorname{tr}$ & 0.2 & 0.9 \\
\hline 41 & Terpinen-4-ol & 1178 & 1177 & 4.2 & 1.1 & 0.1 & - & 0.7 & 0.4 \\
\hline 42 & p-Cymen-8-ol & 1185 & 1185 & 0.3 & 0.1 & - & - & 0.2 & - \\
\hline 43 & Cryptone & 1186 & 1186 & - & - & - & - & - & - \\
\hline 44 & $\alpha$-Terpineol & 1190 & 1190 & 7.0 & 2.5 & $\operatorname{tr}$ & - & 1.7 & 1.9 \\
\hline 45 & Methyl salicylate & 1194 & 1194 & - & - & - & 0.1 & - & - \\
\hline 46 & Myrtenal & 1196 & 1196 & 0.7 & 0.1 & $\operatorname{tr}$ & - & 0.8 & 0.2 \\
\hline 47 & n-Dodecane & 1205 & 1201 & 3.5 & $\operatorname{tr}$ & - & - & 2.6 & - \\
\hline 48 & trans-Piperitol & 1207 & 1207 & 0.2 & - & - & - & - & - \\
\hline 49 & trans-Carveol & 1219 & 1218 & - & - & - & 0.8 & 6.7 & 2.2 \\
\hline 50 & n-Hexyl 2-methyl butanoate & 1236 & 1236 & 0.2 & - & - & - & - & - \\
\hline 51 & Neral & 1238 & 1240 & - & - & - & - & - & 0.1 \\
\hline 52 & Carvone & 1244 & 1244 & - & - & - & - & 0.1 & $\operatorname{tr}$ \\
\hline 53 & Geraniol & 1254 & 1255 & - & - & - & $\operatorname{tr}$ & - & 0.1 \\
\hline 54 & Geranial & 1268 & 1269 & - & 0.1 & - & - & - & - \\
\hline
\end{tabular}


Table 4 (continued)

\begin{tabular}{|c|c|c|c|c|c|c|c|c|c|}
\hline \multirow[t]{3}{*}{ No. } & \multirow[t]{3}{*}{ Compounds } & \multirow{2}{*}{\multicolumn{2}{|c|}{$\begin{array}{r}\text { Retention } \\
\text { index }\end{array}$}} & \multicolumn{6}{|l|}{$\%$} \\
\hline & & & & \multicolumn{2}{|c|}{ N. binaloudensis } & \multicolumn{2}{|c|}{ N. cataria } & \multicolumn{2}{|c|}{ N. assurgens } \\
\hline & & $\mathbf{R I}^{\mathbf{a}}$ & $\mathbf{R}^{\mathbf{b}}$ & 1st year & 2nd year & 1st year & 2nd year & 1st year & 2nd year \\
\hline 55 & Bornyl acetate & 1287 & 1287 & - & - & - & - & - & - \\
\hline 56 & p-Cymen-7-ol & 1290 & 1290 & - & - & - & - & $\operatorname{tr}$ & - \\
\hline 57 & Thymol & 1290 & 1290 & 1.7 & - & - & - & - & - \\
\hline 58 & Carvacrol & 1297 & 1297 & 0.6 & - & & - & 0.1 & - \\
\hline 59 & $\delta$-Elemene & 1336 & 1336 & - & - & - & - & - & 0.1 \\
\hline 60 & 4a- $\alpha, 7-\alpha, 7 a-\alpha-$ Nepetalactone & 1358 & 1360 & 1.2 & 59.7 & 17.9 & 19.8 & 34.7 & 55.5 \\
\hline 61 & Neryl acetate & 1366 & 1366 & - & - & - & - & - & - \\
\hline 62 & Methyl p-anisate & 1374 & 1374 & - & & - & & 0.1 & \\
\hline 63 & $\alpha$-Copaene & 1376 & 1376 & 0.2 & - & - & - & - & - \\
\hline 64 & $\beta$-Bourbonene & 1384 & 1384 & 1.0 & - & - & - & - & - \\
\hline 65 & Geranyl acetone & 1386 & 1387 & - & - & - & - & - & - \\
\hline 66 & 4a- $\alpha, 7-\alpha, 7 a-\beta-$ Nepetalactone & 1388 & 1388 & 0.9 & - & 72.8 & - & 5.7 & - \\
\hline 67 & $4 a-\alpha, 7-\beta, 7 a-\alpha-$ Nepetalactone & 1391 & 1392 & - & 0.9 & 2.5 & 73.9 & - & 2.7 \\
\hline 68 & $\mathrm{n}$-Tetradecane & 1401 & 1402 & 1.4 & - & - & - & 1.4 & - \\
\hline 69 & Methyl eugenol & 1407 & 1407 & - & - & - & - & - & 0.1 \\
\hline 70 & $\beta$-Funebrene & 1413 & 1413 & - & - & - & - & - & - \\
\hline 71 & (E)-Caryophyllene & 1419 & 1421 & - & - & 0.7 & - & 0.2 & 0.5 \\
\hline 72 & $\beta$-Copaene & 1427 & 1427 & 0.1 & - & - & - & - & - \\
\hline 73 & trans- $\alpha$-Bergamotene & 1738 & 1438 & - & - & - & - & - & - \\
\hline 74 & (E)- $\beta$-Farnesene & 1447 & 1447 & - & - & 0.4 & - & - & - \\
\hline 75 & $\alpha$-Humulene & 1545 & 1454 & - & - & 0.1 & $\operatorname{tr}$ & - & 0.1 \\
\hline 76 & allo-Aromadendrene & 1460 & 1460 & - & - & - & - & - & - \\
\hline 77 & (E)- $\beta$-Farnesene & 1458 & 1458 & - & - & - & 1 & - & $\operatorname{tr}$ \\
\hline 78 & $\gamma$-Muurolene & 1475 & 1475 & 0.3 & - & - & & - & - \\
\hline 79 & Germacrene D & 1483 & 1483 & 0.2 & - & - & - & - & 0.1 \\
\hline 80 & Neryl isobutanoate & 1486 & 1486 & - & - & - & - & - & - \\
\hline 81 & (E)- $\beta$-Ionone & 1485 & 1485 & 0.2 & - & - & - & - & - \\
\hline 82 & Valencene & 1493 & 1493 & 0.1 & - & - & - & - & - \\
\hline 83 & Bicyclogermacrene & 1496 & 1496 & - & - & - & - & 0.1 & 0.2 \\
\hline 84 & (Z)- $\alpha$-Bisabolene & 1510 & 1510 & 0.3 & - & - & - & - & - \\
\hline 85 & $\delta$-Cadinene & 1524 & 1524 & 0.4 & - & - & - & - & - \\
\hline 86 & Spathulenol & 1578 & 1578 & - & 0.1 & - & $\operatorname{tr}$ & 0.9 & 0.4 \\
\hline 87 & Caryophyllene oxide & 1583 & 1583 & - & 0.1 & 0.6 & 1 & 0.6 & 0.4 \\
\hline 88 & Humulene epoxide II & 1610 & 1610 & - & - & $\operatorname{tr}$ & - & - & - \\
\hline 89 & 6,10,14-trimethyl-2-Pentadecanone & 1846 & 1846 & - & - & - & - & 0.4 & - \\
\hline \multicolumn{2}{|c|}{ Total identified (\%) } & & & $92.4 \%$ & $95 \%$ & $99 \%$ & $98.3 \%$ & $96.6 \%$ & $99.8 \%$ \\
\hline \multicolumn{2}{|c|}{ Number of compounds } & & & 26 & 37 & 25 & 32 & 45 & 50 \\
\hline
\end{tabular}

tr, traces $(<0.05 \%)$. ${ }^{a}$ Retention index in the first year. ${ }^{\mathrm{b}}$ Retention index in the second year determined on HP-5MS capillary column.

The EO of the composition of various Nepeta species grown in Iran was extensively investigated [29-33]. The essential oil of $N$. binaludensis, an endemic species to Iran, was studied by Mohammadpour et al. [30] who identified 65 components including 1,8-cineol (68.31\%), $\alpha$-terpineol (5.24\%), $\beta$-pinene (4.7\%), $\delta$-terpineol (2.57\%), and $\alpha$-pinene $(1.54 \%)$ [30]. The most abundant constituents in $N$. binaludensis investigated by Rustaiyan and Nadji [32] were 1,8-cineole (42\%), nepetalactone (25\%), linalol (4\%), $\alpha$-terpineol (4\%), and $\beta$-pinene (3\%). According to the literature, the EO composition of N. assurgens, an Iranian endemic species was previously reported only by Moradalizadeh et al. [31] who identified $4 a \alpha, 7 \alpha, 7 \mathrm{a} \alpha-\mathrm{NL}$, $4 \mathrm{a} \alpha, 7 \alpha, 7 \mathrm{a} \beta$-NL, 1, 8-cineole, $\alpha$-pinene, $\beta$-pinene, and $\alpha$-terpineol as the main components.

The differences between wild and cultivated medicinal plants growing in various regions were reported in terms of EO composition. The chemical profiles shown in the present study are quite similar to the ones previously reported in other studies, except for the amounts 
Table 5: Essential oil yields of Nepeta species reported in previous studies.

\begin{tabular}{llllr}
\hline Species & Condition & Region & Oil & Reference \\
\hline N. cataria & collected & Moroccan & $1.02 \%$ & {$[8]$} \\
N. cataria & collected & Iran & $0.3-0.9 \%$ & {$[9]$} \\
N. binaludensis & collected & Iran & $0.5 \%$ & {$[11]$} \\
N. cataria & cultivated & Lithuania & $5.94 \mathrm{mg} / \mathrm{g}$ & {$[12]$} \\
N. cataria & cultivated & Iran & $2.5 \%$ & {$[19]$} \\
$N$. cataria & cultivated & Egypt & $0.117-0.253 \%$ & {$[20]$} \\
N. cataria & cultivated & Egypt & $0.19-2.5 \%$ & {$[21]$} \\
N. cataria & collected & Turkey & $0.74 \%$ & {$[27]$} \\
N. cataria & collected & Poland & $0.45-0.80 \%$ & {$[28]$} \\
\hline
\end{tabular}

of some compounds. For instance, the main EO constituents of $N$. cataria were $4 \mathrm{a}-\alpha, 7-\alpha, 7 \mathrm{a}-\alpha-\mathrm{NL}$, and $4 \mathrm{a}-\alpha, 7-\beta, 7 \mathrm{a}-$ $\alpha$-NL, in the range of $78-91 \%$, in plants cultivated in Iran [19], and 20.81-35.15\%, in plants cultivated in Egypt [20, 21]. In the EO from $N$. cataria cultivated in Lithuania, $4 \mathrm{a} \alpha, 7 \alpha, 7 \mathrm{a} \beta-\mathrm{NL}(50.16 \%)$ was the dominant constituent, in addition to $4 \mathrm{a} \alpha, 7 \alpha, 7 \mathrm{a} \alpha-\mathrm{NL}(35.64 \%)$ and $4 \mathrm{a} \alpha, 7 \beta, 7 \mathrm{a} \alpha-\mathrm{NL}$ $(1.80 \%)$, which represented $87.60 \%$ of the total EO volatiles [12]. Again, NLs were the major compounds in the EO of N. cataria from Turkey, Poland, and Morocco, but their percentages were different [19].

It is well known that variability in quality and quantity of secondary metabolites in plants is mainly influenced by the environmental factors possibly modifying the expression levels of the key genes/enzymes involved in the biosynthesis of the EO constituents. Therefore, introduction of Nepeta species into the cultivation under different growing conditions represents a promising perspective in the field of medicinal plants. Mashhad province is a region with semi-arid weather and an annual rainfall less than $200 \mathrm{~mm}$; in these conditions, water deficit and high temperatures represent the limiting factors for Nepeta grown in the summer. Therefore, timing of sowing as well as management of nutrients and water could improve the economic Nepeta production.

In addition, the phytochemical differences could also be due to the existence of different Nepeta chemotypes [18-20]. Accordingly, on the basis of our results, $N$. binaloudensis and $N$. assurgens are characterized by high percentages of and NLs and 1,8-cineole, whereas $N$. cataria EO was composed mainly of NLs.

\section{Conclusions}

One of the main aims of local and global medicinal and aromatic plant market is to take a decisive step toward the modern, cost effective, and sustainable plant cultivation and production, particularly in Iran. In this context, the environmental conditions of Mashhad (Iran) are suitable to cultivate Nepeta species and produce EOs with peculiar aromatic traits.

Although the yields of EOs were not rather high, in general, 89 compounds were identified, which is a remarkably higher number compared with the previous reports [12]. Nepeta assurgens with high contents of $4 \mathrm{a}-\alpha, 7-\alpha, 7 \mathrm{a}-\alpha-\mathrm{NL}$ and 1,8-cineole was not reported previously. Evaluation of EOs of Nepeta species in the present study confirmed information on the existence of two main chemotypes in the Nepeta genus according to the previous studies. In Iran, cultivated $N$. cataria can be assigned to the NL chemotype, whereas $N$. binaloudensis and $N$. assurgens can be assigned to 1,8-cineole chemotype.

\section{References}

1. Hedge C, Wendelbo P, Aellen P. Studies in the Flora of Afghanistan. Oslo, Norway: Norwegian University Press, 1964.

2. Jamzad Z. Flora of Iran, Lamiaceae. Iran: Research Institute of Forest and Rangelands, Tehran Press, 2012.

3. Amirmohammadi FZ, Azizi M, Neamati SH, Memariani F, Murphy R. Nutlet micromorphology of Iranian Nepeta (Lamiaceae) species. Nord J Bot 2019;37:8-02441.

4. Formisano C, Rigano D, Senatore F. Chemical constituents and biological activities of Nepeta species. Chem Biodivers 2011;8:1783-818.

5. Mihaylova D, Georgieva L, Pavlov A. In vitro antioxidant activity and phenolic composition of Nepeta cataria L. extracts. Int J Appl Sci Technol 2013;1:74-9.

6. Stappen A, Ali N, Tabanca IA, Khan J, Wanner VK, Gochev V, et al. Antimicrobial and repellent activity of the essential oils of two lamiaceae cultivated in western himalaya. Curr Bioact Compd 2015;11:23-30.

7. Skoric M, Gligorijevic N, Cavic M, Ristic M, Misic D, Radulovic S. Cytotoxic activity of Nepeta rtanjensis Diklic and Milojevic essential oil and its mode of action. Ind Crops Prod 2017;100:163-70.

8. Zenasni L, Bouidida H, Hancali A, Boudhane A, Amzal H, Idrissi $A$, et al. The essentials oils and antimicrobial activity of four Nepeta species from Morocco. J Med Plants Res 2008;2:111-4. 9. Zomorodian K, Saharkhiz MJ, Shariati S, Pakshir K, Rahimi MJ, Khashei R. Chemical composition and antimicrobial activities of essential oils from Nepeta cataria L. against common causes of food-borne infections. ISRN Pharm 2012;2012:591953.

10. Joshi N, Sah GC. GC-MS analysis and antimicrobial activity of essential oil of Nepeta coerulescens. Int J Res 2014;3:68-71.

11. Nadjafi F, Koocheki A, Honermeier B, Asili J. Autecology, ethnomedicinal and phytochemical studies of Nepeta binaloudensis Jamzad a highly endangered medicinal plant of Iran. J Essent Oil-Bear Plants 2009;12:97-110.

12. Baranauskienė R, Bendžiuvienė V, Ragažinskienė 0 , Venskutonis PR. Essential oil composition of five Nepeta species cultivated in Lithuania and evaluation of their bioactivities, toxicity 
and antioxidant potential of hydrodistillation residues. Food Chem Toxicol 2019;129:269-80.

13. Asgarpanah J, Sarabian S, Ziarati P. Essential oil of Nepeta genus (Lamiaceae) from Iran: a review. J Essent Oil Res 2014;26:1-12.

14. Sharma A, Cannoo DS. Phytochemical composition of essential oils isolated from different species of genus Nepeta of Labiatae family: a review. Pharmacophore 2013;4:181-211.

15. Ashraf B, Ramak P, Ezatpour B, Talei GR. Biological activity and chemical composition of the essential oil of Nepeta cataria $L$. J Res Pharm 2019;23:336-43.

16. Gkinis G, Iliopoulou D, Roussis V, Tzakou O. Chemical composition and biological activity of Nepeta parnassica oils and isolated Nepetalactones. Z Naturforsch C J Biosci 2003;58:681-6.

17. Nestorovic J, Misic D, Siler B, Sokovic M, Glamoclija J, Ciric A, et al. Nepetalactone content in shoot cultures of three endemic Nepeta species and the evaluation of their antimicrobial activity. Fitoterapia 2010;81:621-6.

18. Kumar V, Mathela CS. Chemical constituents of essential oils of Himalayan Nepeta ciliaris Benth and Senecio nudicaulis BuchHam. Ex D. Don. J Essent Oil Res 2018;30:207-13.

19. Hadi N, Shojaeiyan A, Sefidkon F, Jafari AA. Quantitative and qualitative study of essential oil in some accessions of Nepeta spp and determination of essential oil components ability in intra and inter-specific relationships analysis. Iran J Hortic Sci 2016;49:601-12.

20. Said-Al Ahl H, Naguib NY, Hussein MS. Evaluation growth and essential oil content of catmint and lemon catnip plants as new cultivated medicinal plants in Egypt. Ann Agric Sci 2018;63:201-5.

21. Ibrahim ME, El-Sawi SA, Ibrahim FM. Nepeta cataria L, one of the promising aromatic plants in Egypt: seed germination, growth and essential oil production. J Mater Environ Sci 2017;8:1990-5.

22. Yang L, Wen KS, Ruan X, Zhao YX, Wei F, Wang Q. Response of plant secondary metabolites to environmental factors. Molecules 2018;23:762-80.
23. Ncube B, Finnie JF, Van Staden J. Quality from the field: the impact of environmental factors as quality determinants in medicinal plants. S Afr J Bot 2012;82:11-20.

24. Horvath G, Szabo LG, Héthelyi E, Lemberkovics E. Essential oil composition of three cultivated Thymus chemotypes from Hungary. J Essent Oil Res 2006;18:315-7.

25. Lubbe R, Verpoorte R. Cultivation of medicinal and aromatic plants for specialty industrial materials. Ind Crops Prod 2011;34:785-801.

26. Adams RA. Identification of essential oil components by gas chromatography/quadropole mass spectroscopy. Corp Carol Stream, IL: Allured Press, 2011.

27. Adiguzel A, Ozer H, Sokmen M, Gulluce M, Sokmen A, Kilic H, et al. Antimicrobial and antioxidant activity of the essential oil and methanol extract of Nepeta cataria. Pol J Microbiol 2009;58:69-76.

28. Klimek B, Modnicki D. Terpenoids and sterols from Nepeta cataria L. var. citriodora (Lamiaceae). Acta Pol Pharm 2005;62:231-5.

29. Dabiri M, Sefidkon F. Chemical composition of Nepeta crassifolia Boiss. \& Buhse oil from Iran. Flavour Fragr J 2003;18:225-7.

30. Mohammadpour N, Emami SA, Asili J. Identification of volatile oil components of Nepeta binaludensis Jamzad by GC-MS and 13C-NMR. Methods and evaluation of its antimicrobial activity. J Essent Oil-Bear Plants 2013;16:102-7.

31. Moradalizadeh M, Akhgar MR, Jafari S. Chemical composition of the essential oil of Nepeta assurgens Hausskn. Bornm. Trends Modern Chem 2012;2:31-5.

32. Rustaiyan A, Nadji K. Composition of the essential oils of Nepeta ispahanica Boiss and Nepeta binaludensis Jamzad from Iran. Flavour Fragr J 1999;14:35-7.

33. Sefidkon F, Jamzad Z, Mirza M. Chemical composition of the essential oil of five Iranian Nepeta species (N. crispa, N. mahanensis, $N$. ispahanica, $N$. eremophila and $N$. rivularis). Flavour Fragr J 2006;21:764-7. 